\title{
Does corporate governance lead to a change in the capital structure?
}

\author{
Muhammad Ateeq Ur Rehman ${ }^{1}$, Ramiz Ur Rehman ${ }^{2}$ and Awais Raoof ${ }^{3}$ \\ Lahore Business School, University of Lahore, Pakistan, \\ Tel: +92-4235321456-60; Fax: +92-4235321760 \\ 1'Lecturer, Email; hateeq-ur-rehman@hotmail.com \\ ${ }^{2}$ Assistant Professor, Email; ramiz_rehman@hotmail.com \\ ${ }^{3}$ Associate Professor, Email; awais_raoof@hotmail.com
}

\begin{abstract}
The study investigates the relationship between corporate governance and capital structure of randomly selected 19 banks of Pakistan. The data was collected from financial statements issued by financial institution and multiple regression model was applied to find the relationship between the variables. Results show that there is no relationship between corporate governance and capital structure in the banking sector of Pakistan. Furthermore, our findings show that all independent variables are positively related with capital structure except ownership concentration which affects adversely to capital structure but overall there is an insignificant relationship between capital structure and corporate governance.
\end{abstract}

Keywords: Corporate Governance, Capital Structure, Board Independence.

\section{INTRODUCTION}

"Corporate Governance" refers to the set of laws and procedures which guide and direct the behavior of corporations, shareholders and managers, in accordance with the state policies and practices. Corporate governance also provides the basis for a stable and productive business environment which protects the interests of internal and external stakeholders. Corporate Governance has become an important and well debated issue in recent years. As Demirag et al., (2000) states that there is a need of an accountable system which controls scandals regarding shareholders, stakeholders and management in corporate world. Codes of best practices originated in early 1990's in the United Kingdom, United States, and Canada is now well established there to protect the corporate stakeholders and their interests.

The Cadbury Report in the U.K. provide influential role to corporate governance and as Mintz (2005) describes, corporate governance plays an important role in constructing business ethics. In addition Government also make get to different regimes to protect the interest of stakeholders, suppliers, shareholders and employees under the umbrella of corporate governance. However, corporate governance remains different regarding various regions due to culture, social values and diverse applicable laws and regulation. There is no specific description of corporate governance. Cadbury (1992) describes corporate governance as "the system by which companies are directed and controlled". In addition, Omet (2006) states corporate governance as an important issue now a days due to different financial crises in Asia, Europe and America. It includes a set of policies and methods which guarantee stakeholders their rights. A set of policies also play an important role in protecting stakeholders and save their investment if good governance is practicized. There are different determinants of corporate governance like; Board Size, Ownership Structure, Board Independence and Financial disclosures, which show the level of safety and security of stake holder's investments.

The main purpose of this study is to examine the relationship between corporate governance and capital structure in banking sector while some work is done on contemporary issues in accordance with Pakistani scenario. The code of corporate governance issued by the Securities \& Exchange Commission of Pakistan (SECP) in 2002 is also applicable to the Asset Management Companies, which manage mutual funds in Pakistan. On behalf of such policies, different variables of corporate governance and capital structure related banking sectors (2005-2006) are included in this study and multiple regressions is applied to check the relationship between corporate governance and capital structure. However, a positive but a weak 
relationship is found between corporate governance and capital structure except ownership concentration which moves adversely with capital structure.

The remaining part of the paper is organized as follows. Section II includes a brief review of literature and Section III discusses the methodology of the contemporary research work. Results and findings are given in Section IV while Section V concludes. At last Appendix provides information regarding multi regressions analysis.

Corporate governance contains various aspects of complex regimes as Zingales (1998) also examines it as a comprehensively broad, multifaceted notion that is enormously relevant, while difficult to define, due to the variety of scope that it encompasses. Maurizio La Rocca (2007) also shows the theoretical work on the same topic and suggests working on empirical analysis while it shows the relationship between Corporate Governance and Capital Structure. Otnet (2006) examines the relationship between corporate governance and capital structure using Jordanian companies' data while assuming ownership structure as a proxy of corporate governance. Moreover, the work indicates that the agency cost arises due to internal and external set of mechanism and ownership structure has positive and negative impact on the capital structure. Firstly, a negative relation between ownership structure and capital structure is due to short term financing. Secondly, a positive relationship between ownership structure and capital structure is due to sustainability in financing and enforcement of block holders (shareholders) to avail the opportunity of high debt.

Friend and Lang (1998) examine that shareholders, having high concentration in firms, play an important role to control and direct the management to take keen interest in benefit of the concentration group. In addition corporate governance regimes also allow shareholders to direct the management for betterment of their investment. Shleifer and Vishny (1997) describe that concentration groups with large share holdings; check the manager's activities better. However, the check and balance not only causes to reduce the agency cost but also resolves the issues between managers and owners. Furthermore, Williamson (1988) examines the relationship between corporate governance and financial instruments. The study explores debt and equity is not alternative to each other but it can be the alternatives in the sense of governance structure while assets should be financed on the basis of same governance structure. In the existence of transaction cost, a firm can take benefit by employing debt due to debt governance while in case of prudence or judgment, firm should employ equity due the equity governance.

On the other hand, Wen et al., (2002) find the relationship between corporate governance and capital structure analyzing the data of Chinese listed companies. The study reveals due to strict rules and regulations, managers of the Chinese firm do not employ debt to keep the risk of default at low level. In addition, three reasons for employing low debt are; the small numbers of directors in the firms, the large numbers of outside directors in the board of directors and the attractive tenure, salary, and bonus of the CEO. Subsequently, Suto (2003) describes the relationship between corporate governance and capital structure before and after the financial crises, describing the agency cost approach. The study analyzes the time series and cross-sectional data obtaining from KLSE, by using different proxy variables for capital structure and corporate governance like; Debt ratio, Profitability ratio, Business risk and top ten ownership shareholders etc. However the commitment in banks for lending and borrowing causes to increase the debt ratio. On the other hand, increase in ownership does not effect on corporate management. Further, the study investigates the foreign ownership reduces the agency cost as well as high debt ratio attracts excessive investments. Moreover, Jensen (1986) seems to be quite keen to analyze how corporate governance directly or indirectly influences the capital structure and firm value. While, Driffield et al., (2007) find that higher ownership concentration has a positive impact on capital structure and firm value. In the case of lower ownership concentration, the relationship depends upon the strictness of managerial decision making which enforce to bring change in the capital structure.

In so far as the no study has found the significant relationship between corporate governance and capital structure. As Modigliani and Miller (1958) describe that there is no relationship between capital structure and firm value. In Pakistan, less work is done to investigate the relation between corporate governance and capital structure. The robust study is the basic work related corporate governance and capital structure in accordance with Pakistani scenario. 


\section{Data and Methodology}

A sample of nineteen listed banks on Karachi Stock Exchange is selected for this study on the basis of convenient sampling technique. The study contains two years data of different variables from 2005-2006 to examine the relationship. The selection of the variables is based on previous relative empirical and descriptive studies. Capital structure is taken as a dependent variable while corporate governance is used as an independent variable in the contemporary work. However, ownership concentration, Board Independence, Managerial Ownership, Board Size, Number of meetings held during the year is used as proxy variables of Corporate Governance.

The following procedure describes the construction of the independent and dependent variables related to capital structure and corporate governance.

Capital Structure $(\mathrm{CS})=$ Long term Debts / Capital Employed.

Ownership Concentration $(\mathrm{OC})=$ Top 20 Share $/$ Total Share.

Board Independence $(\mathrm{BI})=$ Non Executive Directors in the Board / Total Number of Directors.

Managerial Ownership $(\mathrm{MO})=$ Share held by CEO, Directors and Family \& Child /Total Share.

Board Size $(B S)=$ Total Number of Directors

No of meeting during year $($ NMDY $)=$ Total number of meetings held with in one year.

On the basis of these variables we construct the hypothesis as under.

HI: There is a strong relationship between capital structure and corporate governance.

However, we use the panel data which gives the results near to reality causes to decrease the error chances and increase the efficiency. On the other hand, OLS model is applied to find the relation between both independent and dependent variables.
$C S=\alpha+\beta_{1} O C+\beta_{2} B I+\beta_{3} M O+\beta_{4} B S+\beta_{5} N M D Y+\mu_{i}$ In the above model " $\alpha$ " denotes the fixed effect on capital structure and " $\mu \mathrm{i}$ " states an overall standard error of the model where as $\beta_{1}, \beta_{2}, \beta_{3}, \beta_{4}$ and $\beta_{5}$ show the coefficients of the independent variables while $\mathrm{OC}, \mathrm{BI}, \mathrm{MO}, \mathrm{BS}$ and NMDY are the independent variables. In addition, CS represents as a dependent variable of the model.

The study also investigates the correlation matrix between these variables. However a descriptive statistics of dependent and independent variables of the selected banks is also analyzed.

\section{RESULTS AND DISCUSSION}

In Table 1 (Appendix A) the results obtain by applying OLS model shows that there is a weak relationship between corporate governance and capital structure. The power of model is explained by $R$, which shows the overall influence of controlled variables on uncontrolled variables. But here in our results, it states that only $12 \%$ of dependent variable (Capital Structure) is influenced by independent variables (Ownership Concentration, Board Independence Managerial Ownership, Board Size and No of meeting during year used as proxy for Corporate Governance). In addition, the $P$ value is also greater than $5 \%$ which clearly shows the relationship is weak in both variables. Moreover, F-Statistics also shows weak relationship between independent and dependent variables.

In Table 2 (Appendix A) the correlation results show individual relationship among different variables. All the variables are positively correlated with capital structure except Ownership concentration which shows that if there would be one unit change in OC then the CS would be adversely affected by $3 \%$. The rest of the variables are positively related with capital structure. It means that if the variable increases/decreases then CS would also increase/decrease in same direction.

In Table 3 (Appendix A) summary of descriptive statistics is given. The result shows that on average the bank uses $80 \%$ debt in its capital structure and on average basis $77 \%$ ownership remains in the hand of top 20 share holders. In addition, in the banks there is $83 \%$ independence in the board of directors. Moreover, only $10 \%$ of shares are held by directors, CEOs, their family and child. Furthermore, Board size 
remains 8 to 9 on average basis and independence in audit committee is approximately $92 \%$ in randomly selected banks in Pakistan. Numbers of meetings in a year are held from 6 to 7 . There are $16 \%$ to $20 \%$ chances of variability in the variables except BS and NMDY. The other result regarding these variables is given in Table 3 (Appendix A).

Table 1. Multiple Regression Results

\begin{tabular}{|c|c|c|c|c|}
\hline Variable & Coefficient & Std. Error & t-Statistic & Prob. \\
\hline Constant & 0.638 & 0.264 & 2.413 & 0.020 \\
\hline $\mathrm{OC}$ & -0.149 & 0.168 & -0.887 & 0.380 \\
\hline $\mathrm{BI}$ & 0.070 & 0.274 & 0.255 & 0.800 \\
\hline $\mathrm{MO}$ & 0.140 & 0.190 & 0.736 & 0.467 \\
\hline BS & 0.031 & 0.017 & 1.820 & 0.078 \\
\hline NMDY & 0.004 & 0.013 & 0.347 & 0.731 \\
\hline R-squared & 0.126 & Durbin-Watson stat & & 1.839 \\
\hline Adjusted R-squared & -0.043 & Mean dependent var & & 0.808 \\
\hline S.E. of regression & 0.170 & S.D. dependent var & & 0.166 \\
\hline Sum squared resid & 0.893 & Akaike info criterion & & -0.545 \\
\hline Log likelihood & 17.354 & Schwarz criterion & & -0.243 \\
\hline Prob(F-statistic) & 0.619 & F-statistic & & 0.744 \\
\hline
\end{tabular}

Table 2. Correlation Coefficients between different variables

\begin{tabular}{|l|l|l|l|l|l|l|}
\hline \multicolumn{1}{|c|}{ Correlation } & \multicolumn{1}{c|}{ CS } & \multicolumn{1}{c|}{ OC } & \multicolumn{1}{c|}{ BI } & MO & BS & NMDY \\
\hline CS & 1.000 & & & & & \\
\hline OC & -0.039 & 1.000 & & & & \\
\hline BI & 0.137 & -0.041 & 1.000 & & & \\
\hline MO & 0.110 & 0.351 & 0.157 & 1.000 & & \\
\hline BS & 0.284 & 0.209 & 0.224 & 0.038 & 1.000 & \\
\hline NMDY & 0.038 & 0.341 & 0.167 & 0.215 & -0.002 & 1.000 \\
\hline
\end{tabular}

Table 3. Descriptive Statistics

\begin{tabular}{|l|c|c|c|c|c|c|}
\hline & CS & OC & BI & MO & BS & NMDY \\
\hline Mean & 0.808 & 0.770 & 0.829 & 0.099 & 8.605 & 6.579 \\
\hline Standard Error & 0.027 & 0.031 & 0.018 & 0.026 & 0.293 & 0.388 \\
\hline Median & 0.855 & 0.800 & 0.860 & 0.020 & 8.000 & 6.000 \\
\hline Mode & 0.840 & 0.690 & 0.870 & 0.050 & 8.000 & 5.000 \\
\hline Standard Deviation & 0.166 & 0.194 & 0.111 & 0.161 & 1.809 & 2.390 \\
\hline Sample Variance & 0.028 & 0.038 & 0.012 & 0.026 & 3.272 & 5.710 \\
\hline Kurtosis & 9.709 & 2.545 & 2.552 & 3.178 & 3.009 & -0.147 \\
\hline Skewness & -2.982 & -1.574 & -1.295 & 1.973 & 1.497 & 0.919 \\
\hline Confidence Level (95.0\%) & 0.055 & 0.064 & 0.036 & 0.053 & 0.595 & 0.785 \\
\hline
\end{tabular}


The figure 1 in (Appendix A) shows the trend of the different variables has constant behavior which states there is a weak relationship between capital structure and corporate governance. The attitude of the data does not have a strong non-stationary behavior except NMDY and MO.

\section{Fig 1. Behavior analysis of different variable}

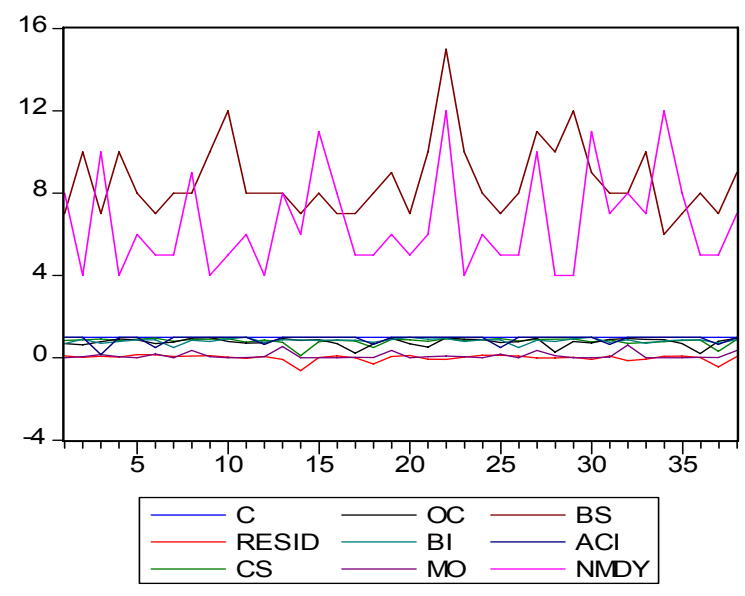

\section{CONCLUSION:}

Corporate governance is a set of rules and regulations to protect the interest of stakeholder, suppliers, shareholders and management. It is the most important issue now a day due to different scandals in business organization all around the world. The main purpose of corporate governance is good governance. In Pakistan SECP (2002) issued codes of ethics for asset management companies.

The paper examines the relationship between corporate governance and capital structure. The data was collected from randomly selected banks in Pakistan. Capital structure is used as a dependent variable while corporate governance is used as an independent variable. However, Ownership Concentration, Board Independence Managerial Ownership, Board Size and No of meeting during year are used as proxy for Corporate Governance. However, the summary of statistics shows that on average the banks use $80 \%$ debt to finance its assets and on average $77 \%$ of the shares are held by the top 20 shareholders. The chances of variation in independent variables are about 16 to $20 \%$ except BS and NDMY. The findings are not consistent with alternative hypothesis and result shows that there is positive but a weak relationship between capital structure and corporate governance.
The result of this paper encourages other people to work on other sectors in to find the relationship between corporate governance and capital structure. It also persuades exploring the other problems related corporate governance. In addition, it is necessary to investigate why the relationship is so weak. However, the robust work has limitation regarding the time period of the data which can be enhanced in further studies. In addition, other variables of corporate governance may also be included to find the relationship with capital structure.

\section{REFERENCE}

Cadbury Committee Report (1992) Report of the Committee on the Financial Aspects of Corporate Governance. http://www.ecgi.org/codes/country.

Demirag, I.,Sudarsanam,S. and Wright. (2000). Corporate governance.Overview and research agenda. British Accounting Review32: 341-353.

Driffield, N., Mahambare, V. and Pal, S. 2007. How does Ownership Structure Affect Capital Structure and Firm value? Economics of Transition 15: 535-573.

Friend, I and Lang, I. 1988. An Empirical Test of the Impact of Managerial Self-Interest on Corporate Capital Structure. Journal of Finance 43: 271-281.

Jensen, M.1986. Agency cost of free cash flow, Corporate Finance and Takeovers. American Economic Review 76: 323-339.

Modigliani, F. and Miller, M. (1958), "the Cost of Capital, Corporation Finance and the Theory of Finance", American Economic Review, Vol. 48 No. 1, pp. 26197.

Mintz, S. M. 2005. Corporate Governance in an International Context: Legal Systems, Financing Patterns and Cultural Variables. Corporate Governance13: 582-597.

Otnet, G. 2006. Ownership Structure and Capital Structure: Evidence from Jordanian Capital Market (1995-2003). Corporate Ownership \& Control 3: Issue 4.

Suto, M. 2003.Capital Structure and Investment Behavior of Malaysian firms in the 1990s: A Study of Corporate Governance before the Crisis. Corporate Governance 11: Number 1.

Shleifer, A and Vishny, R. W. 1997. A Survey of Corporate Governance. Journal of Finance 2: 737-783.

Wen, Y., Rwegasira, K. and Bilderbeek, J.2002. Corporate Governance and Capital Structure Decision of Chinese Listed Companies. Corporate Governance 10: 75-83.

Williamson, O. E.1988. Corporate Finance and Corporate Governance. The Journal of Finance 3: 567-591.

Zingales, L.1998. The New Palgrave Dictionary of Economics and the Law, Macmillan, London. Corporate governance: 